\title{
Serum Cholesteryl Ester Transfer Protein Concentrations Are Associated with Serum Levels of Total Cholesterol, Beta-Lipoprotein and Apoproteins in Patients with Type 2 Diabetes Mellitus
}

\author{
Y. Inukai K. Ito K. Hara A. Yamazaki K. Takebayashi Y. Aso T. Inukai \\ Department of Internal Medicine, Koshigaya Hospital, Dokkyo University School of Medicine, Koshigaya, Japan
}

\section{Key Words}

Cholesteryl ester transfer protein • Diabetes mellitus •

Cholesterol $\cdot \beta$-Lipoprotein $\cdot$ Apoprotein

\begin{abstract}
Objective: To investigate the role of serum cholesterol ester transfer protein (CETP) and the metabolism of various lipids including apoproteins in patients with type 2 diabetes. $\mathbf{M a}$ terials and Methods: The relationships between serum concentrations of CETP and various lipids and apoproteins were investigated in 193 patients with type 2 diabetes mellitus and 68 age-matched healthy subjects. Serum CETP concentrations were measured by an enzyme-linked immunosorbent assay. Results: Serum CETP values were lower in diabetic patients than in healthy controls $(p<0.01)$. Female diabetic patients had significantly higher CETP concentrations than male patients. Serum CETP concentrations exhibited a significant positive correlation with serum concentrations of cholesterol (TC) and $\beta$-lipoproteins in diabetic patients $(r=0.485, p=0.013$ ). Patients with relatively high serum concentrations of high-density lipoprotein cholesterol (HDL-C) tended to have much lower CETP concentrations than patients with lower HDL-C concentrations. Serum CETP concentrations showed significant positive correlations with those of apoproteins $B(A p o B ; r=0.384, p=0.024)$ and $E$ (Apo $E ; r=0.341, p=0.035$ ). Conclusion: The data indicate that serum CETP is closely involved in the metabolism of TC, $\beta$-lipoprotein, Apo B and Apo $E$ in type 2 diabetic patients.

Copyright $\odot 2007$ S. Karger AG, Basel
\end{abstract}

\section{KARGER}

Fax +4161306 1234

E-Mail karger@karger.ch

www.karger.com
(C) 2007 S. Karger AG, Basel

$1011-7571 / 07 / 0165-0367 \$ 23.50 / 0$

Accessible online at:

www.karger.com/mpp

\section{Introduction}

High-density lipoprotein cholesterol (HDL-C) has an anti-atherosclerotic function in which it mobilizes cholesterol from accumulations in peripheral tissues and transports it to the liver [1]. Cholesteryl ester transfer protein (CETP) has the ability to transfer cholesterol ester from HDL towards very-low- and low-density lipoproteins (VLDL, LDL) [2], thereby altering the lipid composition of lipoproteins. Similar to lecithin cholesteryl acyl transferase and hepatic triglyceride lipase, CETP is involved in HDL-C metabolism [3, 4]. CETP can potentially modify the characteristics of HDL particles $[1,5]$. Recently, patients have been identified with a point mutation CETP gene and extremely high serum levels of HDL$\mathrm{C}$ [6]. Polymorphism of this gene might account significantly for variability in lipid parameters in type 2 diabetic subjects [7-9].

The pathophysiology of diabetes is known to include disordered lipid metabolism [3]. Accordingly, patients with type 2 diabetes mellitus have a higher incidence of cardiovascular disease than the non-diabetic population [10]. Syndrome X is a concept described by Reaven [11] that various derangements induce development and progression of coronary heart disease. These derangements include hypertension, disordered glucose tolerance, hypertriglyceridaemia, low HDL-C concentrations and insulin resistance. Clinical states associated with a high risk for atherosclerosis are often accompanied by accelerated net cholesterol ester transfer from HDL to VLDL and 


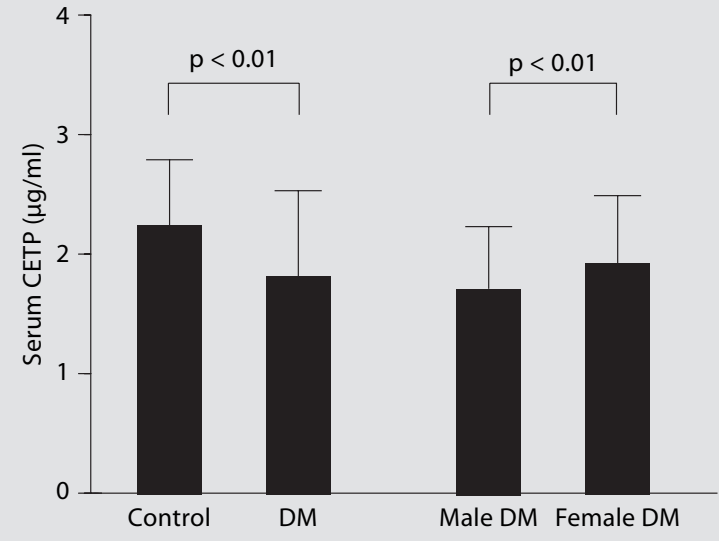

Fig. 1. Comparison of serum concentrations of CETP between healthy control subjects $(n=68)$ and type 2 diabetic patients $(n=$ 193) and between male diabetic patients $(n=99)$ and female diabetic patients $(\mathrm{n}=94)$.

LDL in diabetic patients [12-14]; however, controversy persists as to whether or not serum CETP concentrations have an important influence on lipid metabolism [15]. Furthermore, little is known regarding the relationship between the CETP concentrations and apoprotein metabolism in diabetes. Therefore the relationships between the serum concentration of CETP and the metabolism of various lipids including apoproteins in patients with type 2 diabetes mellitus were investigated.

\section{Subjects and Methods}

Studies were conducted in 193 patients (mean age, $59.0 \pm 10.6$ years) with type 2 diabetes mellitus ( 99 males, mean age $59.4 \pm$ 10.7 years, and 94 females, mean age $58.5 \pm 9.3$ years) and 68 healthy age-matched controls ( 36 males and 32 females, mean age $58.7 \pm 6.9$ years). In the patients, the mean duration of diabetes was $8.2 \pm 2.7$ years, and the mean body mass index (BMI) was 22.9 \pm 4.5 , while the mean BMI in healthy subjects was $22.3 \pm 2.4$.

Serum CETP was determined with a sandwich enzyme-linked immunosorbent assay (ELISA) on a Biomek 2000 laboratory automatic workstation (Beckman Coulter Inc., Fullerton, Calif., USA) according to the manufacturer's instructions $[13,16]$. The intra- and interassay coefficients of variation of this CETP method were 5.8 and $6.7 \%$, respectively.

Serum total cholesterol (TC) was measured by the cholesterol oxidase method using two reagents of chemically modified cholesterol esterase and cholesterol oxidase; triglyceride and serum triglyceride (TG) were measured by the free glycerol reductase method using glycerol kinase and lipoprotein kinase (Roche Diagnostics Co. Ltd., Tokyo, Japan). The intra- and interassay coefficients of variation were 7.8 and $8.1 \%$ for TC and 6.8 and $7.2 \%$ for TG, respectively.

Serum HDL was measured by a direct method using cholesterol oxidase and cholesterol esterase, and the intra- and interassay coefficients of variation were 8.7 and 7.1\%. Serum $\beta$-lipoprotein, VLDL and chylomicrons were measured by a turbidimetric assay (Daiichi Pure Chemicals Co. Ltd., Tokyo, Japan), and then these intra- and interassay coefficients of variation were 9.3 and $8.5 \%$ for $\beta$-lipoprotein, and 10.2 and $8.2 \%$ for VLDL, and then 6.3 and $7.8 \%$ for chylomicrons, respectively.

For the assays of serum apoprotein A1, B and E (ApoA1, ApoB and $\mathrm{ApoE}$ ), the goat antibodies to anti-human ApoA1, ApoB and ApoE were measured by an immunoturbidimetric assay, using a Hitachi-7150 automated analyser (Hitachi Co. Ltd., Tokyo, Japan) and Japanese commercial kits (Daiichi Pure Chemicals Co.). These intra- and interassay coefficients of variation were 5.8 and $6.1 \%$ for ApoA1, 7.0 and $8.3 \%$ for $A$ poB, and 5.3 and $6.6 \%$ for ApoE.

Data were analysed between smoking (62) and non-smoking (131), obese (BMI $\geq 30,16)$ and lean (BMI <30,177), and insulintreated (64) and non-insulin-treated (129) patients. In diabetic patients, serum concentrations of various lipids were compared among 3 groups based on tertiles of serum CEPT levels: first tertile, 64 patients with relatively low CETP levels; second tertile, 65 with relatively middle CETP levels, and third tertile, 64 with relatively high CETP levels.

Data are presented as the mean \pm SD. Comparisons between groups were made using one-way analysis of variance with the Neuman-Keuls multiple comparison test. Correlations between two parameters were examined by linear-regression analysis. A value of $\mathrm{p}<0.05$ was accepted as statistically significant.

\section{Results}

Serum CETP concentrations in type 2 diabetic patients were significantly lower than those in healthy controls ( $p<0.01$; fig. 1). When the lower and upper limits of the normal range for CETP concentrations were defined as 1.14 and $2.92 \mu \mathrm{g} / \mathrm{ml}$, respectively, being the mean \pm 2 SD, 20/193 (10.4\%) of the diabetic patients exhibited low CETP concentrations while 11/193 (5.7\%) had elevated CETP concentrations; the CETP concentrations for the remaining 162 (84.9\%) were within the normal range.

Among diabetic patients, CETP concentrations in females $(1.92 \pm 0.58 \mu \mathrm{g} / \mathrm{ml})$ were significantly higher than in age-matched males $(1.74 \pm 0.47 \mu \mathrm{g} / \mathrm{ml})$ as shown in figure 1 , with $\mathrm{p}<0.01$. However, there was no difference in the normal values for CETP between males and females in healthy control subjects (males: $2.18 \pm 0.34 \mu \mathrm{g} /$ $\mathrm{ml}$, females: $2.35 \pm 0.41 \mu \mathrm{g} / \mathrm{ml}$ ). No difference was found in CETP levels between smoking and non-smoking, obese and lean, and insulin-treated and non-insulintreated patients. 
Table 1. Comparisons of clinical features and serum lipids among healthy control subjects and three groups of type 2 diabetic patients divided according to a distribution of serum concentrations of CETP

\begin{tabular}{|c|c|c|c|c|}
\hline & $\begin{array}{l}\text { Healthy } \\
\text { controls }\end{array}$ & $\begin{array}{l}\text { Group A } \\
\text { (1st tertile) }\end{array}$ & $\begin{array}{l}\text { Group B } \\
\text { (2nd tertile) }\end{array}$ & $\begin{array}{l}\text { Group C } \\
\text { (3rd tertile) }\end{array}$ \\
\hline Number & 68 & $64(33 \%)$ & $65(34 \%)$ & $64(33 \%)$ \\
\hline Serum CETP, $\mu \mathrm{g} / \mathrm{ml}$ & $0.67-4.03$ & $0.38-1.68$ & $1.69-2.24$ & $2.25-3.71$ \\
\hline Age, years & $58.7 \pm 6.9$ & $56.7 \pm 11.5$ & $62.6 \pm 8.4$ & $57.3 \pm 11.7$ \\
\hline Duration of DM, years & - & $7.8 \pm 2.7$ & $8.7 \pm 1.3$ & $8.0 \pm 3.5$ \\
\hline $\mathrm{FPG}, \mathrm{mmol} / \mathrm{l}$ & $5.0 \pm 0.3$ & $8.8 \pm 0.9$ & $8.2 \pm 0.7$ & $8.4 \pm 1.2$ \\
\hline $\mathrm{HbA}_{1 \mathrm{c}}, \%$ & $4.7 \pm 0.6$ & $8.2 \pm 3.0$ & $7.9 \pm 1.4$ & $8.3 \pm 2.7$ \\
\hline BMI (lipids) & $22.3 \pm 2.4$ & $22.4 \pm 4.3$ & $23.4 \pm 3.2$ & $21.8 \pm 5.3$ \\
\hline $\mathrm{TC}, \mathrm{mmol} / \mathrm{l}$ & $4.8 \pm 0.3$ & $4.8 \pm 0.6^{*}$ & $5.7 \pm 0.3$ & $6.9 \pm 0.8^{*}$ \\
\hline $\mathrm{TG}, \mathrm{mmol} / \mathrm{l}$ & $1.2 \pm 0.1$ & $1.6 \pm 0.2$ & $1.7 \pm 0.1$ & $1.8 \pm 0.3$ \\
\hline HDL-C, mmol/l & $1.6 \pm 0.2$ & $1.4 \pm 0.2$ & $1.4 \pm 0.1$ & $1.2 \pm 0.2$ \\
\hline$\beta$-Lipoprotein, mg/dl & $375.4 \pm 42.6$ & $435.6 \pm 57.6^{*}$ & $487.9 \pm 24.9$ & $533.7 \pm 6.9^{*}$ \\
\hline VLDL, mg/dl & $63.8 \pm 18.0$ & $122.7 \pm 33.7$ & $129.4 \pm 23.1$ & $148.3 \pm 31.37$ \\
\hline CLM, mg/dl & $42.8 \pm 8.7$ & $64.6 \pm 14.5$ & $72.3 \pm 7.3$ & $74.3 \pm 18.6$ \\
\hline ApoA1, g/l & 1.42 & $121.4 \pm 23.4$ & $108.5 \pm 7.4$ & $111.7 \pm 18.6$ \\
\hline ApoB, g/l & $0.815 \pm 6.4$ & $84.6 \pm 7.6^{*}$ & $102.4 \pm 5.4$ & $127.8 \pm 20.3^{*}$ \\
\hline ApoE, g/l & $0.049 \pm 0.9$ & $5.9 \pm 2.3$ & $6.2 \pm 0.4$ & $7.7 \pm 1.4^{*}$ \\
\hline
\end{tabular}

Each data point represents the mean $\pm \mathrm{SD}$. DM = Diabetes mellitus; FPG = fasting plasma glucose; $\mathrm{Hb}=$ haemoglobin; CLM $=$ chylomicron. ${ }^{*} \mathrm{p}<0.05$ versus values in group $\mathrm{B}$ with the use of one-way analysis of variance with Neuman-Keuls multiple-comparison test.

Serum TC and TG levels in control subjects were $4.8 \pm$ 0.3 and $1.2 \pm 0.1 \mathrm{mmol} / \mathrm{l}$, respectively (table 1 ). In diabetic patients, no significant differences were found in serum TG, chylomicrons, VLDL or ApoA1 concentrations among the three tertiles of CETP levels. However, patients in the first tertile exhibited significantly lower values for TC, $\beta$-lipoprotein and ApoB than those in the second tertile $(p<0.05)$. Patients in the third tertile group had significantly higher concentrations of ApoE in addition to higher TC, $\beta$-lipoprotein and $\mathrm{ApoB}$ concentrations than patients in the second tertile $(\mathrm{p}<0.05)$. Patients in the first tertile showed a tendency toward increased serum HDL$\mathrm{C}$, and those in the third group tended to have decreased HDL-C compared to those in the second tertile, but the differences were not significant.

Although no significant correlation between serum CETP and haemoglobin $A_{1 c}$ levels was observed, serum CETP levels showed significant positive correlations with TC $(\mathrm{p}=0.013)$ and $\beta$-lipoprotein $(\mathrm{p}=0.017$; fig. 2$)$. Patients with high concentrations of HDL-C $(>80 \mathrm{mg} / \mathrm{dl})$ tended to have particularly low serum CETP concentrations, while those with high $\beta$-lipoprotein concentrations (>500 mg/dl) had significant elevations in CETP compared to patients with $\beta$-lipoprotein concentrations less than $500 \mathrm{mg} / \mathrm{dl}$. Serum concentrations of both ApoB and
ApoE showed significant positive correlations with serum CETP concentrations in type 2 diabetic patients $(\mathrm{p}=0.024, \mathrm{p}=0.035$, respectively; fig. 3 ). No significant correlation was found between serum CETP concentrations and lipoprotein metabolism in healthy subjects. The correlation coefficients and $\mathrm{p}$ values between serum CETP and serum lipids were 0.165 and 0.25 for TC, 0.187 and 0.16 for $\beta$-lipoprotein, 0.245 and 0.13 for $A p o B$, and 0.119 and 0.11 for ApoE, respectively.

\section{Discussion}

CETP is a critical protein for regulating both HDL-C and LDL-C metabolism in patients with hyperlipidaemia [13], while hypertriglyceridaemia enhances the transfer activity of CETP [17]. It has generally been accepted that the serum CETP concentrations reflect CETP activity measured using exogenous lipoprotein substrates [18]. Disagreement exists as to whether serum CETP concentrations are increased or decreased in type 2 diabetes [15]. Our data showed that generally serum CETP concentrations were significantly lower in patients than in a healthy control group, although $5.7 \%$ of patients had elevated CETP concentrations. This finding is similar to other re- 

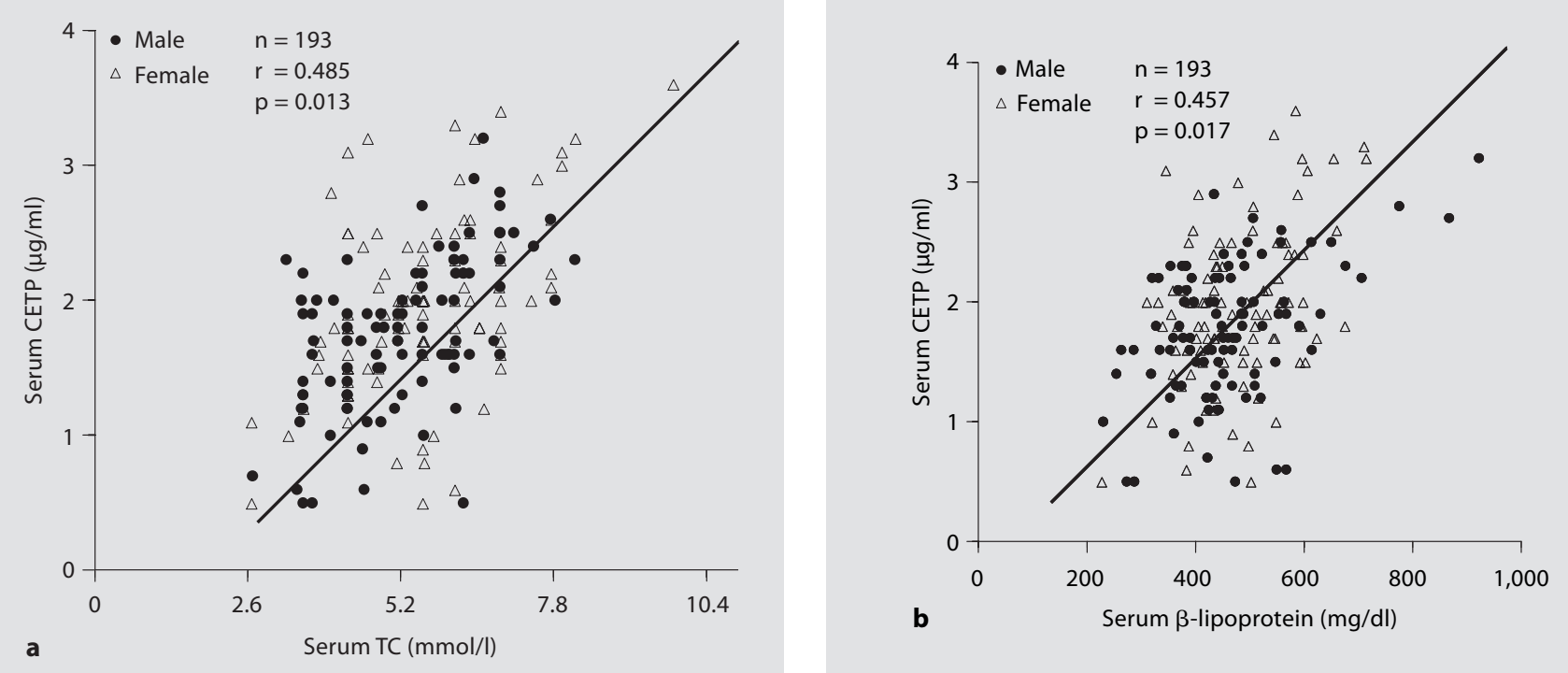

Fig. 2. Correlation between serum concentrations of CETP and serum values of TC (a) and of $\beta$-lipoprotein (b) in type 2 diabetic patients.
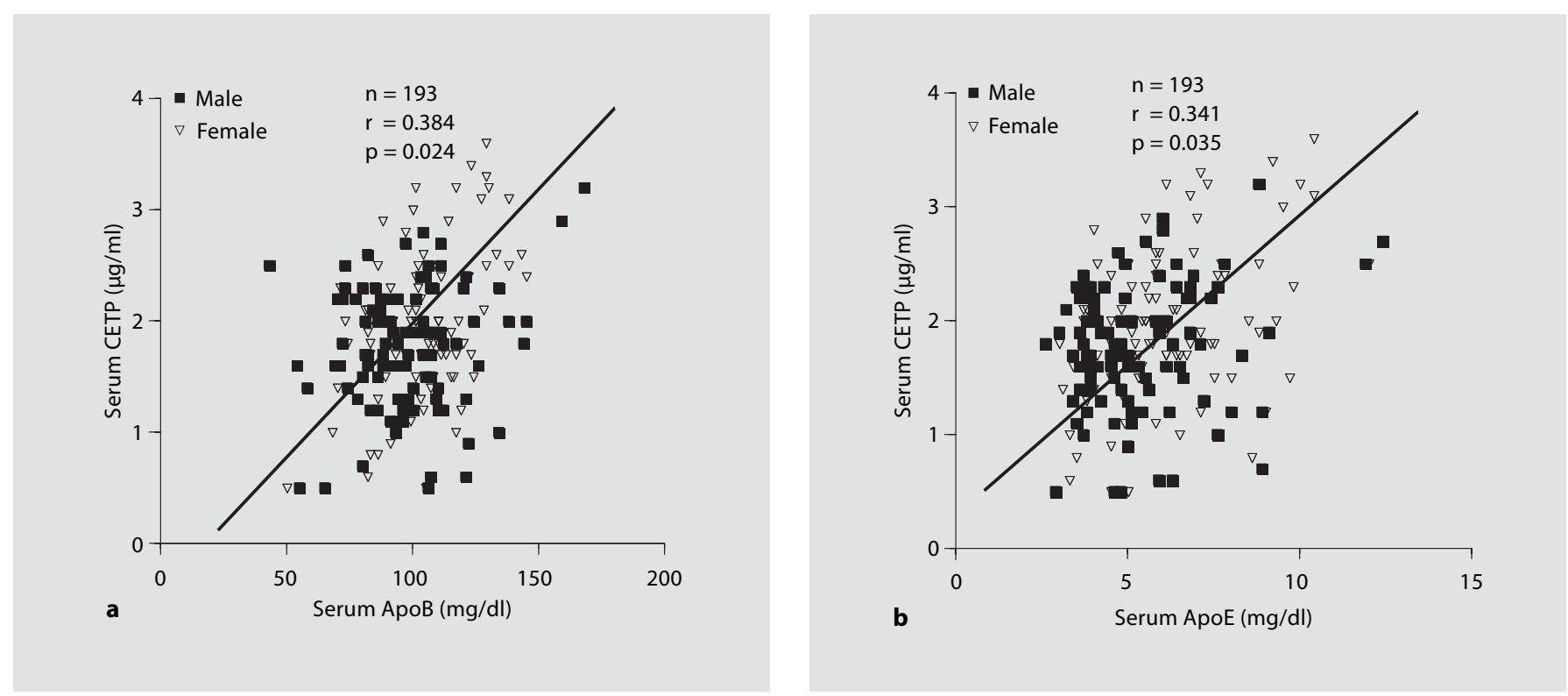

Fig. 3. Correlation between serum levels of CETP and serum ApoB (a) and of ApoE (b) in type 2 diabetic patients.

ports [19-21] but not to others $[5,14,22-24]$ in which CETP concentration was approximately the same in diabetic subjects and normal controls $[5,14,22]$ or elevated in type 1 or type 2 diabetic patients $[23,24]$ and diabetic cynomolgus monkeys [12]. The discrepancies could be due to differences in assay method, type of diabetes, genetic or ethnic background. For example, in the present study BMI $\geq 30$ was classified as obese while for another 
study [25], it was BMI $\geq 32.2$. Equally, insulin infusion in healthy subjects [2] and diabetic patients $[26,27]$ has been shown to decrease plasma CETP activity.

An incidental finding of this study was the significantly higher CETP concentration in female than in agematched male patients. Interpretation of this finding is difficult. CETP activity has been reported to be increased in cigarette-smoking men with type 1 diabetes and microvascular complications; high CETP activity may have contributed to an unfavourable lipoprotein profile observed in these patients [28]. A genetic polymorphism of CETP seems to exert a modulating role in males with type 2 diabetes $[9,29]$, which could result in a difference of serum CETP concentrations between gender. It is plausible that the anti-rat CETP polyclonal antibody used in this study was not completely able to recognize all the different polymorphic isoforms of human CETP. This limitation might be relevant to the reasons given for gender differences.

Castle et al. [30] demonstrated that genetically modified KKAy-CETP mice retained the principal characteristics of control KKAy mice, except that their plasma HDL levels were extremely lowered ( $25 \pm 6$ vs. $159 \pm 25 \mathrm{mg} / \mathrm{dl})$, which represents evidence that CETP transfers cholesteryl esters from HDL to VLDL and LDL. Jones et al. [5] reported a negative correlation between CETP activity and serum HDL-C in diabetic patients. Our present data indicate that patients with low serum CETP concentrations tended to have increased amounts of HDL-C in serum, while patients with high CETP concentrations tended to show lower HDL-C concentrations; however, the correlations did not attain significance. A study of diabetic patients with nephropathy indicated that elevations of CETP activity were probably not responsible for lowering of HDL-C [1]. The lack of correlation between serum CETP concentration and HDL-C is commonly observed. Taken together, CETP-related lowering of HDL-C could be due to other factors affecting lipid metabolism in diabetes.

In this study, we have shown that CETP concentration has a positive correlation with TC, LDL and also ApoB and ApoE similar to other studies [12-14]. Bagdade et al. [12] emphasized that abnormality in CETP in type 2 diabetes is associated with the VLDL and LDL fraction rather than the HDL fraction, supporting our present results. In type IIa and type IIb hyperlipidaemic patients, plasma concentrations of CETP are reported to have a significant positive correlation with TC and LDL [13], similar to our finding and also with ApoB and ApoE. Using multivariate analysis, another study found that CETP exhibited a close correlation in diabetic patients with variation in the LDL-III subfraction of LDL [14]. However, Elchebly et al.
[15] reported that net cholesterol ester transfer was highly correlated with plasma TG concentration but not with that of LDL-C.

CETP can exert an atherogenic effect by reducing the cholesterol in HDL [3], which raises the possibility of progressive development of atherosclerosis in the $5.7 \%$ of diabetic patients found to have high CETP concentrations in the present study. Furthermore, postprandial hyperlipidaemia [10] and postprandial HDL metabolism [31] are atherogenic in diabetes, and alterations of CETP and hepatic lipase activity affect postprandial lipidaemia. Based on these reports, we need to examine CETP not only in the fasting state, but also under postprandial conditions. However, it has recently been reported that the Taq $1 \mathrm{~B}$ polymorphism of intron 1 of the CETP gene is related to myocardial infarction in type 2 diabetic patients [32], necessitating the need in future of not only serum CETP levels, but also the polymorphism of the CETP gene.

\section{Conclusion}

The present data show that an increase in serum CETP is significantly correlated with elevations of TC, $\beta$-lipoprotein, $A$ poB and ApoE in type 2 diabetic patients. A sustained increase in the serum concentrations of CETP, a key protein in lipid metabolism, might be involved in the development and progression of atherosclerosis in diabetic patients.

\section{Acknowledgement}

We appreciate Mr. Kenya Kawamura, an associate director of the Clinical Laboratory Department in Koshigaya Hospital, Dokkyo University School of Medicine, for his kind technical advice to all lipid assays.

References

Med Princ Pract 2007;16:367-372 371
Kahri J, Groop PH, Elliott T, Viberti G, Taskinen MR: Plasma cholesteryl ester transfer protein and its relationship to plasma lipoproteins and apolipoprotein A-I-containing lipoproteins in IDDM patients with microalbuminuria and clinical nephropathy. Diabetes Care 1994;17:412-419.

2 Riemens SC, van Tol A, Stulp BK, Dullaart RPF: Influence of insulin sensitivity and TaqlB cholesteryl ester transfer protein gene polymorphism on plasma lecithin: cholesterol acyltransferase and lipid transfer protein activities and their response to hyperinsulinemia in non-diabetic men. J Lipid Res 1999;40:1467-1474. 
3 Erkelens DW: Diabetic dyslipidaemia. Eur Heart J 1998;19(suppl):H27-H40.

-4 Riemens SC, van Tol A, Sluiter WJ, Dullaart RP: Plasma phospholipid transfer protein activity is lowered by 24 -hour insulin and acipimox administration: blunted response to insulin in type 2 diabetic patients. Diabetes 1999;48:1631-1637.

5 Jones RJ, Owens D, Brennan C, Collins PB, Johnson AH, Tomkin GH: Increased esterification of cholesterol and transfer of cholesteryl ester to apo B-containing lipoproteins in type 2 diabetes: relationship to serum lipoproteins A-I and A-II. Atherosclerosis 1996;119:151-157.

-6 Inazu A, Brown ML, Hesler CB, Agellon LB, Koizumi J, Takata K, Maruhama Y, Mabuchi H, Tall AR: Increased high density lipoprotein levels caused by a common cholesteryl ester transfer protein gene mutation. $\mathrm{N}$ Engl J Med 1990;323:1234-1238.

7 Dullaart RP, Hoogenberg K, Riemens SC, Groener JE, van Tol A, Sluiter WJ, Stulp BK: Cholesteryl ester transfer protein gene polymorphism is a determinant of HDL cholesterol and of the lipoprotein response to a lipid-lowering diet in type 1 diabetes. Diabetes 1997;46:2082-2087.

-8 Bernard S, Moulin P, Lagrost L, Picard S, Elchebly M, Ponsin G, Chapuis F, Berthezene F: Association between plasma HDLcholesterol concentration and Taq1B CETP gene polymorphism in non-insulin-dependent diabetes mellitus. J Lipid Res 1998;39: 59-65.

9 Durlach A, Clavel C, Girard-Globa A, Durlach V: Sex-dependent association of a genetic polymorphism of cholesteryl ester transfer protein with high-density lipoprotein cholesterol and macrovascular pathology in type II diabetic patients. J Clin Endocrinol Metab 1999;84:3656-3659.

10 Coppack SW: Postprandial lipoproteins in non-insulin-dependent diabetes mellitus. Diabet Med 1997;14(suppl 3):S67-S74.

11 Reaven GM: Role of insulin resistance in human disease. Diabetes 1988;37:1595-1607.

$\checkmark 12$ Bagdade JD, Wagner JD, Rudel LL, Clarkson TB: Accelerated cholesteryl ester transfer and altered lipoprotein composition in diabetic cynomolgus monkeys. J Lipid Res 1995; 36:759-766.

13 Desrumaux C, Athias A, Bessede G, Verges B, Farnier M, Persegol L, Gambert P, Lagrost L: Mass concentration of plasma phospholipid transfer protein in normolipidemic, type IIa hyperlipidemic, type IIb hyperlipidemic, and non-insulin-dependent diabetic subjects as measured by a specific ELISA. Arterioscler Thromb Vasc Biol 1999; 19:266275.
14 Tan KC, Shiu SW, Chu BY: Roles of hepatic lipase and cholesteryl ester transfer protein in determining low density lipoprotein subfraction distribution in Chinese patients with non-insulin-dependent diabetes mellitus. Atherosclerosis 1999;145:273-278.

15 Elchebly M, Porokhov B, Pulcini T, Berthezene F, Ponsin G: Alterations in composition and concentration of lipoproteins and elevated cholesteryl ester transfer in non-insulin-dependent diabetes mellitus (NIDDM). Atherosclerosis 1996;123:93-101.

16 Chang CK, Tso TK, Snook JT, Zipf WB, Lozano RA: Sandwich enzyme-linked immunosorbent assay for plasma cholesteryl ester transfer protein concentration. Clin Biochem 1999;32:257-262.

17 Mann CJ, Yen FT, Grant AM, Bihain B: Mechanism of plasma cholesteryl ester transfer in hypertriglyceridemia. J Clin Invest 1991;88:2059-2066.

18 Yamashita S, Hui DY, Wetterau JR, Sprecher DL, Harmony JAK, Sakai N, Matsuzawa Y, Tarui S: Characterization of plasma lipoproteins in patients heterozygous for human plasma cholesteryl ester transfer protein (CETP) deficiency. Metabolism 1991;40: 756-763.

19 Kahri J, Syvanne M, Hayashibe H, Asayama K, Nakane T, Kobayashi K, Amemiya S, Nakazawa S: Decreased activity of plasma cholesteryl ester transfer protein in children and adolescents with insulin-dependent diabetes mellitus. Acta Paediatr 1999;88:1067-1070.

-20 Dullaart RP, De Vries R, Scheek L, Borggreve SE, Van Gent T, Dallinga-Thie GM, Ito M, Nahgano M, Sluiter WJ, Hattori H, Van Tol A: Type 2 diabetes mellitus is associated with differential effects on plasma cholesteryl ester transfer protein and phospholipids transfer protein activities and concentrations. Scand J Clin Lab Invest 2004;64:205-215.

21 MacLean PS, Vadlamudi S, MacDonald KG, Pories WJ, Barakat HA: Suppression of hepatic cholesteryl ester transfer protein expression in obese humans with the development of type 2 diabetes mellitus. J Clin Endocrinol Metab 2005;90:2250-2258.

22 Lottenberg SA, Lottenberg AM, Nunes VS, McPherson R, Quintao EC: Plasma cholesteryl ester transfer protein concentration, high-density lipoprotein cholesterol esterification and transfer rates to lighter density lipoproteins in the fasting state and after a test meal are similar in type II diabetics and normal controls. Atherosclerosis 1996;127: 81-90.
23 Bagdade JD, Kelley DE, Henry RR, Eckel RH, Ritter MC: Effects of multiple daily insulin injections and intraperitoneal insulin therapy on cholesteryl ester transfer and lipoprotein lipase activities in NIDDM. Diabetes 1997;46:414-420.

24 Riemens SC, van Tol A, Sluiter WJ, Dullaart RP: Elevated plasma cholesteryl ester transfer in NIDDM: relationships with apolipoprotein B-containing lipoproteins and phospholipid transfer protein. Atherosclerosis 1998;140:71-79.

25 Viberti G, Lachin J, Holman R, Zinman B, Haffner S, Kravitz B, Heise MA, Jones NP, O’Neill MC, Freed MI, Kahn SE, Herman WH; for the ADOPT Study Group. A diabetes outcome progression trial (ADOPT): baseline characteristics of type 2 diabetic patients in North America and Europe. Diabet Med 2006;23:1289-1294.

26 Sutherland WH, Walker RJ, Lewis-Barned NJ, Pratt H, Tillman HC: The effect of acute hyperinsulinemia on plasma cholesteryl ester transfer protein activity in patients with non-insulin-dependent diabetes mellitus and healthy subjects. Metabolism 1994;43: 1362-1366.

27 Arii K, Suehiro T, Yamamoto M, Ito H, Hashimoto K: Suppression of plasma cholesteryl ester transfer protein activity in acute hyperinsulinemia and effect of plasma nonesterified fatty acid. Metabolism 1997;46: $1166-1170$

28 Dullaart RP, Groener JE, Dikkeschei BD, Erkelens DW, Doorenbos H: Elevated cholesteryl ester transfer protein activity in IDDM men who smoke. Possible factor for unfavorable lipoprotein profile. Diabetes Care 1991;14:338-341.

-29 Ukkola O, Savolainen MJ, Salmela PI, von Dickhoff K, Kesaniemi YA: DNA polymorphisms at the locus for human cholesteryl ester transfer protein (CETP) are associated with macro- and microangiopathy in noninsulin-dependent diabetes mellitus. Clin Genet 1994;46:217-227.

30 Castle CK, Kuiper SL, Blake WL, Paigen B, Marotti KR, Melchior GW: Remodeling of the HDL in NIDDM: a fundamental role for cholesteryl ester transfer protein. Am J Physiol 1998;274:E1091-E1098.

-31 Durlach V, Attia N, Zahouani A, Leutenegger M, Girard-Globa A: Postprandial cholesteryl ester transfer and high density lipoprotein composition in normotriglyceridemic non-insulin-dependent diabetic patients. Atherosclerosis 1996;120:155-165.

- 32 Yilmaz H, Agchan B, Karaali ZE, Isbir T: Taq1B polymorphism of CETP gene on lipid abnormalities in patients with type II diabetes mellitus. Int J Mol Med 2004;13:889893 